INTERNATIONAL JOURNAL OF MULTidisciplinARY RESEARCH AND ANALYSis

ISSN(print): 2643-9840, ISSN(online): 2643-9875

Volume 04 Issue 12 December 2021

DOI: 10.47191/ijmra/v4-i12-14, Impact Factor: 6.072

Page No.- $1862-1878$

\title{
Marketing Analysis for the Construction of a Business Plan: Analysis of the Restaurant Sector in the Commercial Center of a City Located in the Brazilian's Interior
}

\author{
Cleginaldo Pereira de Carvalho ${ }^{1}$, Douglas Alves da Silva ${ }^{2}$ \\ ${ }^{1,2}$ Department of Industrial Engineering, University of the State of São Paulo, Faculty of Engineering of Guaratinguetá, Avenida Dr. \\ Ariberto Pereira da Cunha 333, Pedregulho, Guaratinguetá, São Paulo, Brazil, Zip Code:12.516-410, São Paulo, Brazil
}

\begin{abstract}
Nowadays, when competitiveness has become a frequent factor among companies, they must be prepared and structured, in order to acquire competitive advantages in the market. The present work aims to analyze the restaurant market in the commercial center of the city of Lorena, state of São Paulo - SP, providing information on the profile of consumers, companies that compete in the market and influencing aspects in decision making in choosing the preferred establishment, thus providing the necessary subsidies for the elaboration of a possible business plan. The investigation was conducted through a bibliographic review and a market research applied to regulars in the commercial center of the municipality. The results obtained demonstrate the existence of a heterogeneous market, composed of consumers of the most varied ages, occupations and preferences for companies already established in the local commerce. The study also presented as the most relevant factors in the process of choosing the preferred restaurant the quality of the products, the service and the variety. Thus, the feasibility of proceeding to a detailed business plan, incorporating financial and marketing aspects, is concluded.
\end{abstract}

KEYWORDS: Restaurants. Strategy. Business plan. Market analysis.

\section{INTRODUCTION}

According to the Brazilian Association of Food Industries (ABIA) (2020), the food industry showed a growth of $114 \%$ in the period between 2011 and 2019, being the food service, characterized as meals away from home, responsible for the increment of 96 billion reais (R\$) in the comparison between $2011 / 2009$, a growth of $110 \%$.

Given this scenario of economic rise, managers of companies such as restaurants, must identify the factors that affect the levels of public satisfaction and must direct their limited resources to these factors, in order to promote the image of a place differentiated from other competitors, delivering a noticeable value for money, increasing customer satisfaction and the possibility of their loyalty (CAKICI; AKGUNDUZ; YILDIRIM, 2019, our translation).

In this sense this work aims to analyze the market of restaurants in the city of Lorena, in the state of São Paulo - SP, through information raised through a field research. The elements raised in the study should be able to munificiate a business plan, contributing to the strategic planning and reducing the risks for the investor.

\section{THEORETICAL BACKGROUND}

\subsection{Corporate Strategy}

According to Ocke, Guedes and Silva (2020), the current market dynamics impacts on the consumer's behavior that starts to present a behavior characterized by a lower degree of loyalty in a market of competitive offers and encouraged to vary their choices of purchase options, causing the companies that offer products and services of food outside the home have to improve their management techniques and service delivery.

Also, Yemchuk and Arpul (2020) highlight the need for leadership in promoting the efficiency of all resource investment in the use of technologies, in analyzing the experiences of other companies in the segment, in prioritizing the satisfaction of consumer needs, in analyzing and monitoring the market and the conditions of the economy. 


\section{Marketing Analysis for the Construction of a Business Plan: Analysis of the Restaurant Sector in the Commercial Center of a City Located in the Brazilian's Interior}

Yembergenov and Zharylkasinova (2019) point out that the competition for customers is getting tougher every day and this is the factor that should direct managers in the elaboration of the business strategy that will give the company the necessary uniqueness, since each organization has its own structure and management system that must be guided by a clear business strategy.

According to Lobato, Filho, and Torres (2005), the concept of strategy, which was initially used by military organizations, was appropriated by business and its development connected with social transformations and, consequently, with the business world. Silva (2011), defines strategy as the direction of resources to achieve its objectives, within a given environmental context and taking into account the organizational characteristics. Professor and consultant Ansoff (1977) defines strategy as one of several sets of decision rules to guide the behavior of an organization.

\subsection{Strategic Planning}

When it comes to the management of organizations, issues related to business feasibility, the necessary investment, the availability of local human resources, the best time for launches, the competition, consumer habits, how to manage and the inherent risks that may impact the results gain relevance for their managers (LEE et al., 2020, our translation).

Thus, the planning of activities, through a consistent environmental analysis, is a key factor in driving the organization, guiding the decisions of those responsible and contributing to the achievement of the established goals. Studies in the area of strategic planning in the restaurant market, such as that of Hladkyi et al. (2019) and Siopa et al. (2015), attribute the success of this type of venture to several aspects such as the generation of consumption experience through the quality of the service offered, the role of the physical environment in creating emotions, the geographical location of the venture, and the cost-benefit ratio.

Yembergenov and Zharylkasinova (2019) also emphasize the importance of forming an adequate system of indicators, which take into account financial aspects, such as expenses and revenues, according to organizational specifics.

\subsection{Analysis of the Environment}

\subsubsection{External environment analysis}

In a highly competitive market like restaurants, satisfying customers should be the critical goal of every company that wants to prosper. However, adequate quality is dependent on industry-specific factors such as: demand, competition, the available variety of products, the inseparability of product and consumption, the intangibility of services, and the quality of available labor; as well as several other factors that affect the level of service offered.

Kukanja, Omerzel, and Bukovec (2017) suggest that understanding customer needs is the first step in providing quality services, with the discovery of expectations being the best way to manage consumer demands, thus enabling the creation and implementation of business strategies. Rajput and Gahfoor (2020) states that the positive association of food quality, service quality, physical environment quality, and restaurant customer satisfaction arouse the consumer's desire to return to the service providing establishment. The analysis of the external environment aims at the anticipation of possible opportunities and threats that directly affect the mission, vision, and organizational objectives. For this, according to Lobato, Filho and Torres (2005, p. 46), "the organization needs to go beyond the simple future projection of past events and the examination of facts and data that a re visible, anticipating what is relevant to the construction of its future of the organization". For Almeida (2003) the ability of organizations to observe changes in the environment is becoming increasingly important so that, through the construction of scenarios, they are able to evaluate their positioning and anticipate the construction of their future. According to the author, the environmental analysis is divided into two stages: the analysis of the general environment and of the sectorial environment.

\subsubsection{Analysis of the general environment}

The general environment is formed by elements that characterize and shape the society in which the organization is inserted. Its analysis aims to identify the external factors that may generate direct or indirect impacts on the development of a company (PINTO, 2016). According to Pinto (2016, p. 61), "the external environment analysis is the initial stage of the strategic planning process and aims to discover information that will be used in the second stage of establishing the organizational guidelines and setting the objectives". Hitt, Ireland and Hoskisson (2011) describe the existence of six segments that make up the external environment, with varying degrees of impact, but which impose the challenge of scanning, monitoring, predicting and evaluating the elements that may generate changes, signal trends, opportunities and threats. Chart 1 presents the segments and the main elements that compose them. 
Marketing Analysis for the Construction of a Business Plan: Analysis of the Restaurant Sector in the Commercial Center of a City Located in the Brazilian's Interior

Chart 1 - General environment - elements and segments

\begin{tabular}{|l|l|}
\hline \multicolumn{1}{|c|}{ SEGMENTO } & ELEMENTOS \\
\hline Demográfico & Tamanho, estrutura etária, distribuição geográfica, mistura étnica e distribuição de renda. \\
\hline Econômico & Natureza e rumo da economia na qual uma empresa compete ou possa competir. \\
\hline Político/Jurídico & $\begin{array}{l}\text { Área na qual a organização e os grupos influentes competem por atenção, recursos e } \\
\text { influência na elaboração de leis que regulamentam a relação entre os países. }\end{array}$ \\
\hline Sociocultural & Atitudes e os valores culturais da sociedade. \\
\hline Tecnológico & $\begin{array}{l}\text { Instituições e atividades envolvidas na criação de conhecimento e na transformação desse } \\
\text { conhecimento em produtos, processos e materiais. }\end{array}$ \\
\hline Global & $\begin{array}{l}\text { Novos mercados relevantes, os mercados existentes em transformação, eventos políticos } \\
\text { importantes e as características culturais e institucionais do mercado global. }\end{array}$ \\
\hline
\end{tabular}

Fonte: Hitt, Ireland e Hoskisson (2011)

\subsubsection{Analysis of the sectorial environment}

An industry is characterized as a set of companies that propose to produce or market products or services that compete or substitute for one another. The industry analysis has as its objective the prediction of an average level of competitiveness, among competitors and profitability of the sector under analysis. Such predictability contributes to the elaboration of effective strategies and to the previous visibility of the imaginable results as the adoption of the planned measures.

The bibliography on competitive strategy shows that, historically, when companies analyzed the external environment, it was common to limit concentration on direct competitors, after all, as well as understanding the market is important for success, analyzing competitors, checking their strengths and weaknesses, is fundamental (SOUZA; SILVA, 2015). However, Hitt, Ireland and Hoskisson (2011) point out that companies need to be more comprehensive, identifying the current and possible future competitors.

Porter (1993), proposes to perform the analysis of the industry environment through a model composed of the industry analysis and five competitive forces: threat of new entrants, bargaining power of suppliers, bargaining power of buyers, threat of substitute products, and rivalry between competing companies (Figure 3).

Figure 3 - The five competitive forces.

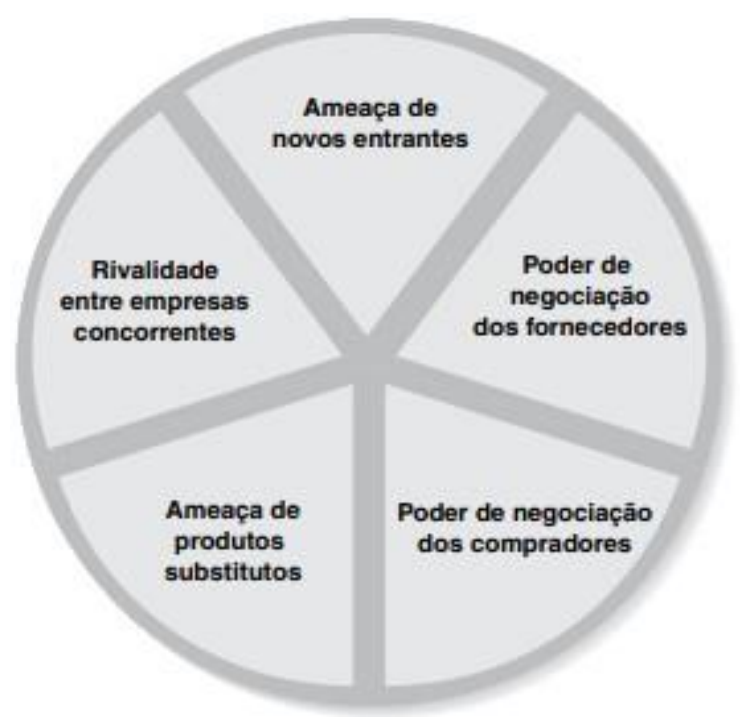

Source: Hitt, Ireland e Hoskisson (2011)

These forces generally have an impact on the competitiveness and profitability of the business sector, and are a result of the intensity of rivalry and the sector's potential (HITT; IRELAND; HOSKISSON, 2011). 
Marketing Analysis for the Construction of a Business Plan: Analysis of the Restaurant Sector in the Commercial Center of a City Located in the Brazilian's Interior

Chart 3 summarizes the elements that directly affect each of the competitive forces. Chart 3 - Factors that influence competitive forces

\begin{tabular}{|c|c|c|}
\hline FORÇA COMPETITIVA & INFLUENCIADORES & FATORES \\
\hline \multirow[t]{4}{*}{ Ameaça de novos entrantes } & \multirow{4}{*}{$\begin{array}{lrr}\text { Barreiras de entrada } & \\
\text { Retaliações dos } & \text { atuais } \\
\text { competidores } & & \\
\end{array}$} & Histórico de retaliação na indústria \\
\hline & & $\begin{array}{l}\text { Existência de empresas com grandes recursos } \\
\text { disponíveis }\end{array}$ \\
\hline & & Crescimento lento do setor \\
\hline & & $\begin{array}{l}\text { Existência de empresas com alta dependência do } \\
\text { setor }\end{array}$ \\
\hline \multirow{7}{*}{$\begin{array}{l}\text { Poder de negociação dos } \\
\text { fornecedores }\end{array}$} & \multirow{7}{*}{$\begin{array}{lcc}\text { Força do fornecedor } & \text { na } \\
\text { negociação com } & \text { os } \\
\text { compradores } & & \\
\end{array}$} & Disponibilidade de fornecedores \\
\hline & & Importância estratégica do fornecedor \\
\hline & & Importância do cliente para o fornecedor \\
\hline & & Grau de diferenciação do produto \\
\hline & & Existência de produtos ou serviços substitutos \\
\hline & & Custos de mudança de fornecedores \\
\hline & & $\begin{array}{l}\text { Possibilidade de integração para frente por parte } \\
\text { dos fornecedores }\end{array}$ \\
\hline \multirow{8}{*}{$\begin{array}{l}\text { Poder de negociação dos } \\
\text { compradores }\end{array}$} & \multirow{8}{*}{$\begin{array}{l}\text { Força do comprador na } \\
\text { negociação com a empresa }\end{array}$} & Número de compradores \\
\hline & & Importância dos compradores \\
\hline & & Importância para o comprador \\
\hline & & Produtos ou serviços padronizados \\
\hline & & Custo de mudança de fornecedor \\
\hline & & Existência de produtos ou serviços substitutos \\
\hline & & Nível de informação do comprador \\
\hline & & $\begin{array}{l}\text { Possibilidade de integração retrógrada por parte } \\
\text { dos compradores }\end{array}$ \\
\hline \multirow{3}{*}{$\begin{array}{l}\text { Ameaça de produtos } \\
\text { substitutos }\end{array}$} & \multirow{3}{*}{$\begin{array}{l}\text { Grau de pressão dos } \\
\text { produtos substitutos }\end{array}$} & Percepção relativa de valor dos produtos \\
\hline & & Custo de mudança de produtos \\
\hline & & $\begin{array}{l}\text { Propensão dos consumidores para substituição } \\
\text { dos produtos }\end{array}$ \\
\hline \multirow{9}{*}{$\begin{array}{l}\text { Rivalidade entre as empresas } \\
\text { concorrentes }\end{array}$} & \multirow[t]{9}{*}{ Grau de rivalidade } & Taxa de crescimento do setor \\
\hline & & Número de concorrentes \\
\hline & & Custos de operação \\
\hline & & Excesso de capacidade no setor \\
\hline & & Ausência de custos de mudança \\
\hline & & Concorrentes divergentes \\
\hline & & $\begin{array}{llll}\text { Concorrentes } & \text { com } & \text { grandes } & \text { interesses } \\
\text { estratégicos } & & & \end{array}$ \\
\hline & & Commodities \\
\hline & & Barreiras de saída elevadas \\
\hline
\end{tabular}

Source: Adapted from Lobato, Filho and Torres (2005) 


\section{Marketing Analysis for the Construction of a Business Plan: Analysis of the Restaurant Sector in the Commercial Center of a City Located in the Brazilian's Interior}

\subsubsection{Internal environment analysis}

Studies in the areas of knowledge that involve management and strategic planning have shown that the reason for a company's existence goes beyond serving the interests of its shareholders. An organization is inserted in a context of interaction with various actors, such as: employees, customers, suppliers and others; configuring what are known as stakeholders (MCGEE; PRUSAK, 1994). Kotler and Keller (2012, p. 50) point out that "one thing is to realize attractive opportunities, another is to have the ability to make the best of them", for this, organizations must be able to systematically assess, with some frequency, their strengths (strengths) and weaknesses (weaknesses). The strengths of a company are internal characteristics capable of contributing to the achievement of the mission, vision, and objectives previously established. The weaknesses, on the other hand, refer to the deficiencies that expose the organization to external threats and that can hinder the fulfillment of the mission and vision statements, as well as the established objectives.

\subsection{SWOT Analysis}

A company's strategy undergoes regular updates as internal conditions or the environment in which it operates are constantly changing. In this sense, strategic management consists of analyses, decisions, and actions taken by organizations to create or sustain a competitive advantage. Strategies are assumed to be responsive and not static, being able to monitor progress and adapt whenever necessary. For this reason, it is essential to have accurate knowledge of what occurs in both the internal and external environments (PINTO, 2016).

SWOT analysis is a management tool widely employed as part of the strategic planning of organizations. The term SWOT comes from English and represents the initials of the words: strengths (strengths), weaknesses (weaknesses), opportunities (opportunities) and threats (threats). Through this type of analysis, according to Pereira (2015), it is possible to examine the internal advantages and disadvantages of a company in relation to other competitors and their potential impact, positive or negative, on competitiveness in the market in which it operates.

A company's strategy undergoes regular updates as internal conditions or the environment in which it operates are constantly changing. In this sense, strategic management consists of analyses, decisions, and actions taken by organizations to create or sustain a competitive advantage. Strategies are assumed to be responsive and not static, being able to monitor progress and adapt whenever necessary. For this reason, it is essential to have accurate knowledge of what occurs in both the internal and external environments (PINTO, 2016).

SWOT analysis is a management tool widely employed as part of the strategic planning of organizations. The term SWOT comes from English and represents the initials of the words: strengths (strengths), weaknesses (weaknesses), opportunities (opportunities) and threats (threats). Through this type of analysis, according to Pereira (2015), it is possible to examine the internal advantages and disadvantages of a company in relation to other competitors and their potential impact, positive or negative, on competitiveness in the market in which it operates.

\subsection{Balanced Scorecard (BSC)}

The contemporary environment, marked by globalization and economic uncertainties, increased the challenges faced by organizations and their leaders. The restaurants, as a type of companies inserted in this context, need to measure the business performance in order to assess the effectiveness of their strategies.

The balanced scorecard (BSC), used as a strategic evaluation tool, indicates that the performance of a company should not be analyzed only through financial indicators, but rather, that it incorporates several metrics capable of helping decision makers in organizational management (BORBA et al., 2018).

According to Galindo (2005), the BSC started to be used worldwide in 1990, being pointed out as an efficient way to promote alignment and strategic control. Since then, the tool has been widely used in companies as a way to focus on critical issues to business, contributing to the control of results and remaining competitive in the market (RODRIGUES; OLIVEIRA, 2020).

The BSC, according to Kaplan and Norton (2000) is a management connection tool for the short, medium and long term, seeking the learning and organizational development, through the strategic unfolding in four perspectives: financial, external customers, internal processes, learning and growth.

\subsection{Business Plan}

According to Dornelas (2018), the true goal of economic activity is to ensure profitability, sustainability of the company and success in competition, so, according to the author, the planning process proves to be fundamental, since one of the main reasons for the failure of many small businesses is the lack of a clear and well-founded concept of economic activity expressed in a business plan. 


\section{Marketing Analysis for the Construction of a Business Plan: Analysis of the Restaurant Sector in the Commercial Center of a City Located in the Brazilian's Interior}

Oliveira, Moretti, and Pozo (2015), highlight that restaurants, like every business, have risks from conception, through planning, implementation, financial investments, to operationalization or management.

According to Dornelas (2018), the business plan or business plan (BP) consists of a document used in the description of a venture and or business model that will sustain it. Pereira (2015) defines it as a written document that describes the current status of an organization and the possible future, constituting a direction for a successful business, describing the company, its future goals and how the entrepreneur intends to achieve them. Thus, we can consider it as a maturation process that facilitates the progress from an idea to a final project.

\section{METHODS}

he work was carried out in the city of Lorena, in the state of São Paulo, in the population follow-up of frequenters of the city's commercial center, where the questionnaires were applied randomly to the inhabitants, according to the distribution of the report of the population profile of the municipality issued by the Brazilian Institute of Geography and Statistics (IBGE) in the year 2018, aged 18 years and older.

The team responsible for the development of the study consists of a researcher, an interviewer and a guiding teacher and was carried out in the period between June and July 2020.

As a data collection technique, discrete and continuous primary data from the company's database and secondary data were used, through a sample survey, by applying questionnaires with standardized responses, in order to extract nominal and ordinal qualitative data for the generation of conclusions about a significant sample of the researched problem (MIGUEL et al., 2012). The use of this tool is due to the possibility of reaching a significant number of people, with low costs and ensuring the anonymity of the respondents (GIL, 2017). The data collection form (Appendix A) was structured containing open and closed questions, according to the objectives to be achieved. The open-ended questions were used so that the respondent could flexibly expose their answers. Meanwhile, the closed questions were directed to the identification of relevant factors to the research result, facilitating the categorization in the tabulation and analysis of the data.

In order to raise the respondents' selection criteria about the relevant attributes in the selection of restaurants, a use was made of ten related comparison questions, which were later analyzed by means of the AHP method. This multicriteria decision-making method, according to Muñoz, Romana, and Ordónez (2016), is a tool capable of reducing subjectivity during decision-making and building filters capable of contributing to the selection among complex alternatives. The use of this method proved to be recommendable since it challenges the interviewee to corroborate his priorities in the process of choosing among several factors. The hierarchy of comparison criteria used is illustrated in Figure 4.

Figure 4 - Hierarchy of comparison criteria.

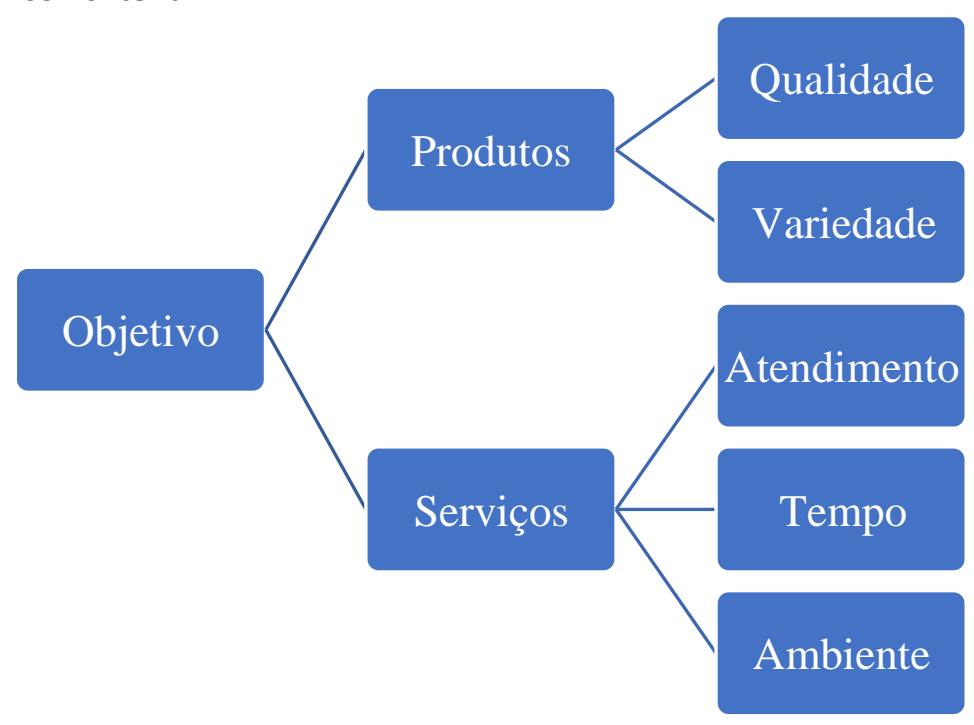

Source: Author's own production

Figure 5 shows a comparison question model of related criteria used in the research, where, by means of a graduated line, the respondent judges if the verified factors have equivalent importance (value 1) or if one criterion has some level of relevance that surpasses the other, when faced. 
Marketing Analysis for the Construction of a Business Plan: Analysis of the Restaurant Sector in the Commercial Center of a City Located in the Brazilian's Interior

Figure 5 - Example of a multicriteria comparison question.

\begin{tabular}{|l|l|l|l|l|l|l|l|l|l|l|}
\hline ATENDIMENTO & 9 & 7 & 5 & 3 & 1 & 3 & 5 & 7 & 9 & QUALIDADE \\
\hline QUALIDADE & 9 & 7 & 5 & 3 & 1 & 3 & 5 & 7 & 9 & VARIEDADE \\
\hline
\end{tabular}

Source: Author's own production

Aiming to identify the profile of potential customers of the work in development, their consumption habits and the perceived image in relation to competitors in the restaurant market, 102 people were interviewed, randomly selected, through an electronic questionnaire distributed through social networks through a face-to-face survey conducted by the interviewer.

The collected content was categorized, coded, and tabulated using electronic spreadsheets, and then studied and applied the appropriate generalizations. For this, the Microsoft Excel ${ }^{\circledR}$ software was used, as it presents benefits in the creation and structuring of quantitative data that allow data analysis, and the presentation of the information generated.

\section{RESULTS AND DISCUSSIONS}

The results obtained from the application of the questionnaire are shown below, with the answers being broken down according to the sequence of questions in the questionnaire.

In the survey on the respondents' place of residence (Figure 6), it is observed that most respondents live in the city of A $56 \%$ and $44 \%$ in another municipality.

Figure 6 - Do you live in the city of A?

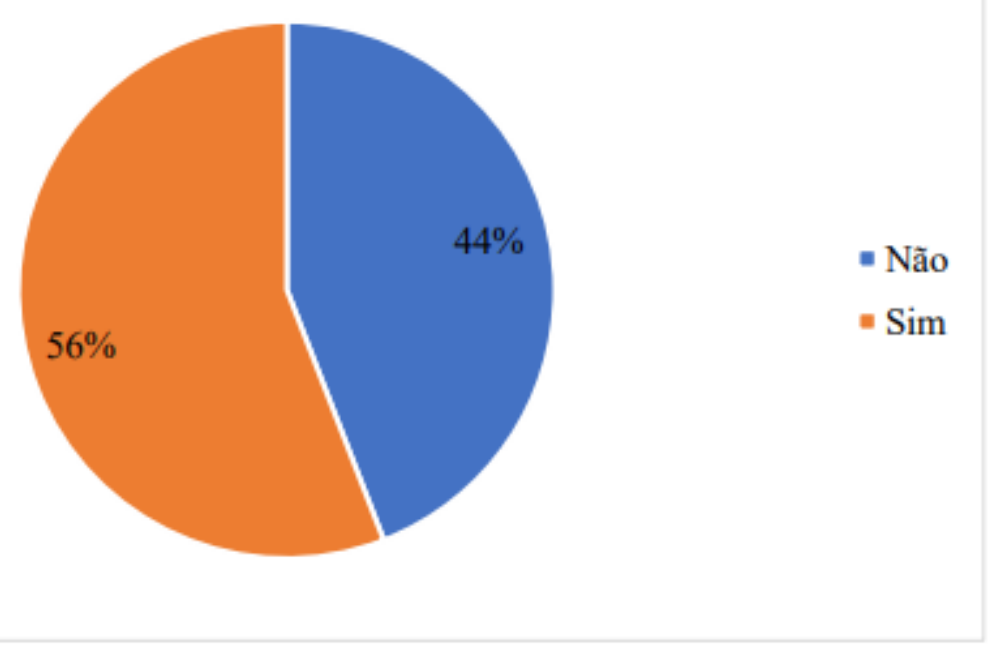

Source: Author's own production

Evaluating the place of residence of the interviewees, there is a potential consumer public in the region, since they are not residents of the municipality and may demand meals away from home. However, the relative balance between the origins of potential customers brings, according to the study presented by Pezenka and Weismayer (2020), different aspects that characterize the provision of a quality service, varying in attributes and needs for satisfaction, between local residents and visitors. In the survey about the respondents' gender (Figure 7), it is noted that most respondents are female (59\%) with only $41 \%$ identified as male. 
Marketing Analysis for the Construction of a Business Plan: Analysis of the Restaurant Sector in the Commercial Center of a City Located in the Brazilian's Interior

Figure 8 - Gender.

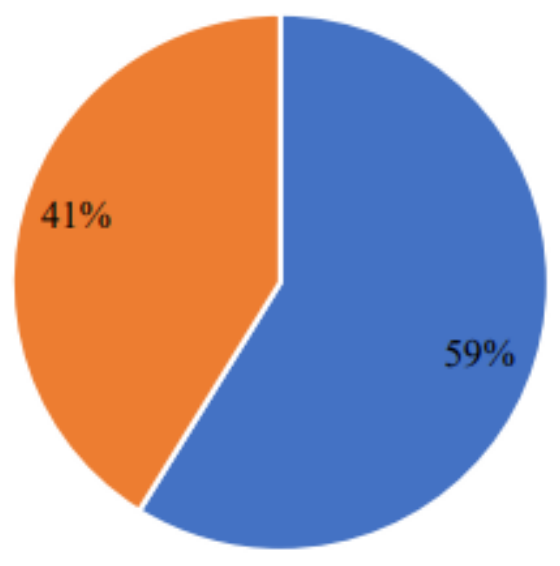

- Feminino

- Masculino

Source: Author's own production

Figure 8 , illustrates that $32 \%$ of the interviewees are above 50 years old, $32 \%$ are between 36 and 50 years old, $30 \%$ are between 26 and 35 years old, and only $6 \%$ are between 18 and 25 years old.

Figure 8 - Age.

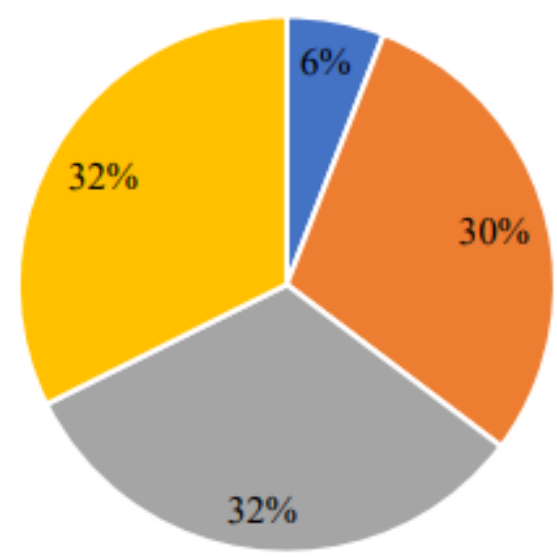

- 18 a 25 anos

$=26$ a 35 anos

$=36$ a 50 anos

$=50$ a 65 anos

Source: Author's own production

The data on the age bracket of the interviewees show a balanced distribution from 26 years old ( $94 \%$ ), which demonstrates the presence of a public in adulthood and economically active.

Figure 9 shows the main occupation of the respondents, being: $26 \%$ employees of private companies, $20 \%$ employees of public companies, $18 \%$ retired, $12 \%$ selfemployed, $9 \%$ entrepreneurs, $9 \%$ students, and $6 \%$ identified themselves as unemployed. 
Marketing Analysis for the Construction of a Business Plan: Analysis of the Restaurant Sector in the Commercial Center of a City Located in the Brazilian's Interior

Figure 9 - Occupancy.

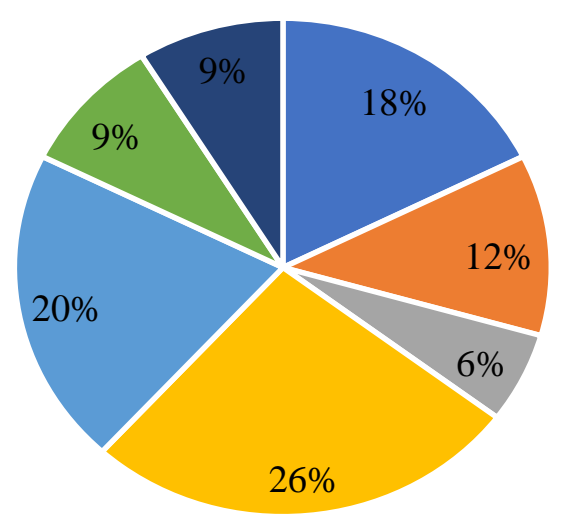

- Aposentado(a)

- Autônomo(a)

- Desempregado(a)

- Empregado(a) de empresa privada

- Empregado(a) de empresa pública

- Empresário(a)

- Estudante

Source: Author's own production

The results obtained about the occupation of the interviewees suggest the presence of a public with a stable source of income, since $64 \%$ said they were employed by public or private companies, or retired.

When asked about professional or student activities in the commercial center of the city of Lorena, according to Figure 10, the majority (88\%) said they do not develop these types of activities at the indicated location, and the other $12 \%$ answered positively to the questioning.

Figure 10 - Do you work or study in the commercial center of the city A?

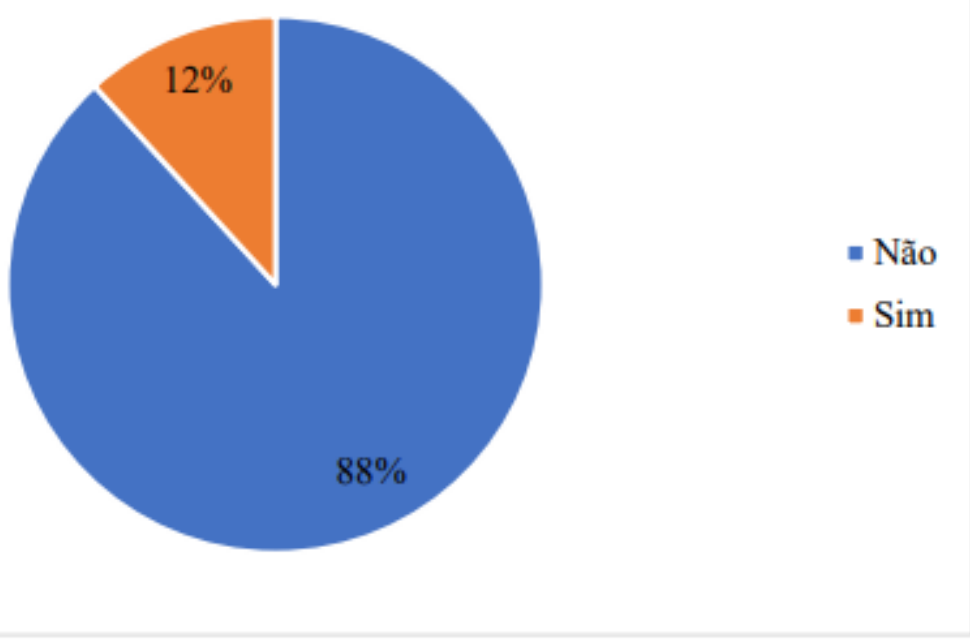

Source: Author's own production

Figure 11 shows the portion of respondents who usually go to restaurants in the commercial center of Lorena, 76\% responded positively and the remaining $24 \%$ said they didn't. 
Marketing Analysis for the Construction of a Business Plan: Analysis of the Restaurant Sector in the Commercial Center of a City Located in the Brazilian's Interior

Figure 11 - Do you frequent restaurants in the city A mall?

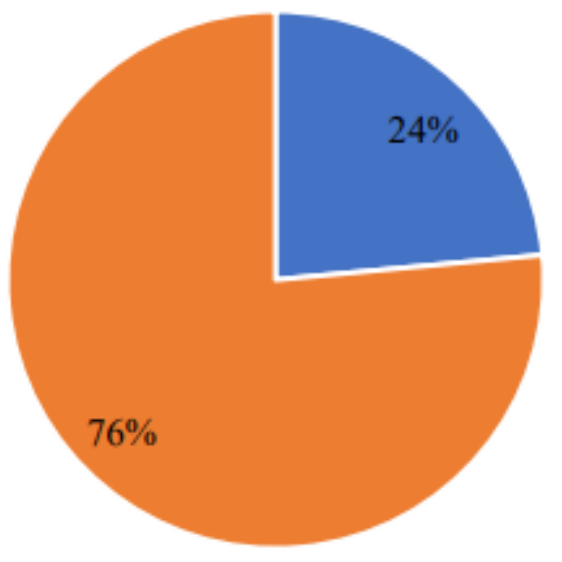

- Não

$=\operatorname{Sim}$

Source: Author's own production

These results demonstrate the need to establish comprehensive action strategies, which are not limited to consumers who perform professional or student activities in the region, since, regardless of this, most respondents make use of restaurant services in the city's commercial center.

When the respondents who said they frequent restaurants in the commercial center of Lorena were asked about up to two aspects that stood out in their preferred establishment, as shown in Figure 12, it was evident as the main attributes: quality (83\%), service $(41.5 \%)$, and variety $(35.1 \%)$. The factors with fewer citations, but still with relevant portions are: price (28.7\%), environment (12.8\%) and location (6.4\%). Loyalty programs such as cards, discounts or prizes were not mentioned.

Figure 12 - What stands out in your favorite restaurant?

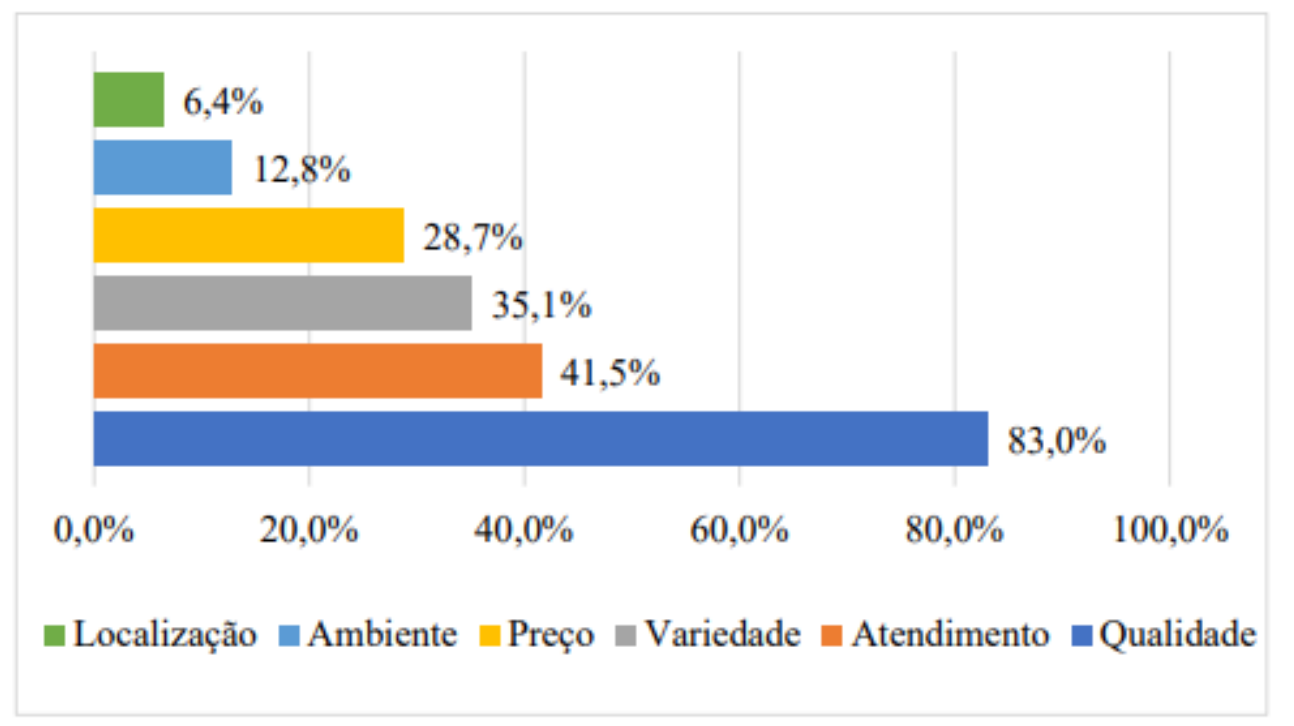

Source: Author's own production

Figure 13 shows which periods of the day the respondents usually go to the restaurants, being possible to choose up to three options. The majority, about $47.9 \%$ of respondents, said they visit the restaurants in the afternoon, $41.5 \%$ at night and $28.7 \%$ in the morning. Thus, we conclude that strategies aimed at those who seek meals during the day have a greater chance of success, since $89.4 \%$ of respondents frequent restaurants at these times of the day. 
Marketing Analysis for the Construction of a Business Plan: Analysis of the Restaurant Sector in the Commercial Center of a City Located in the Brazilian's Interior

Figure 13.

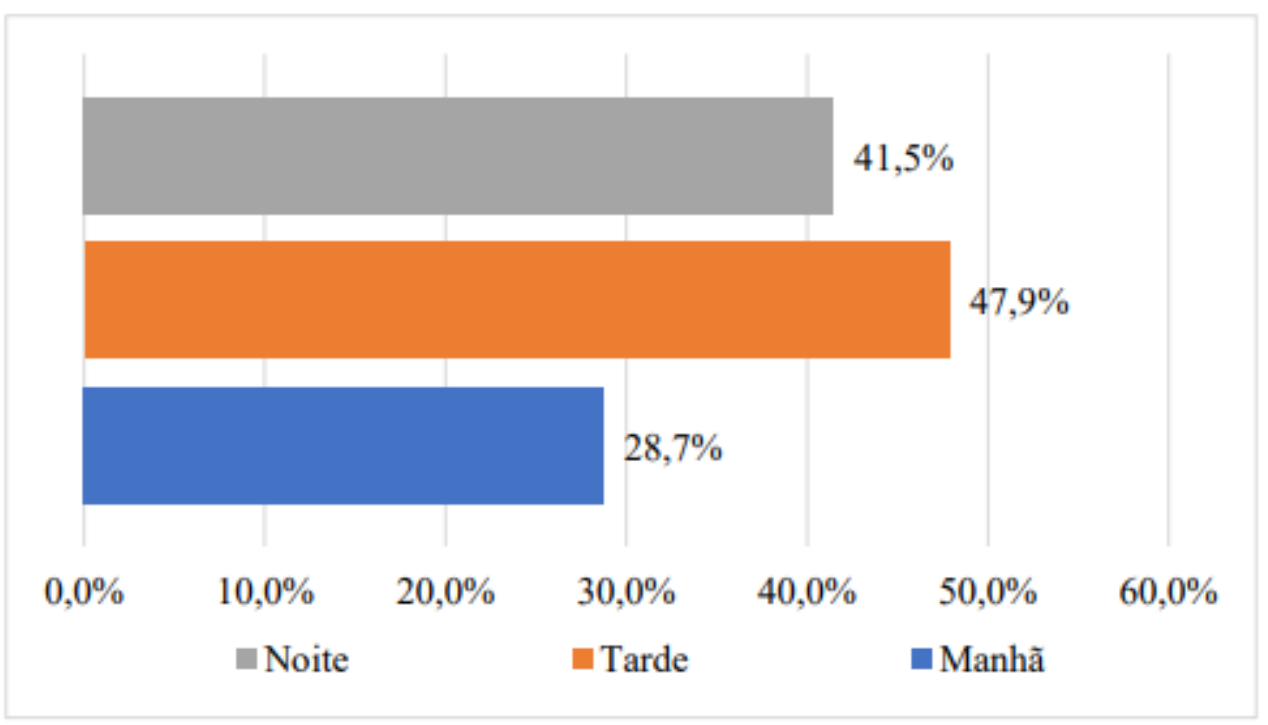

Source: Author's own production

As a highlight, it is worth mentioning that $12.8 \%$ of those who answered this question, said they visit the restaurants more than once a day, and in all cases, the evening was among them.

Figure 15 elucidates the frequency of visits of these customers to the restaurants. The survey pointed out that $30 \%$ of the interviewees visit at least once a month, $28 \%$ once a month, $21 \%$ every other week, and $21 \%$ weekly.

Figure 15 - Frequency.

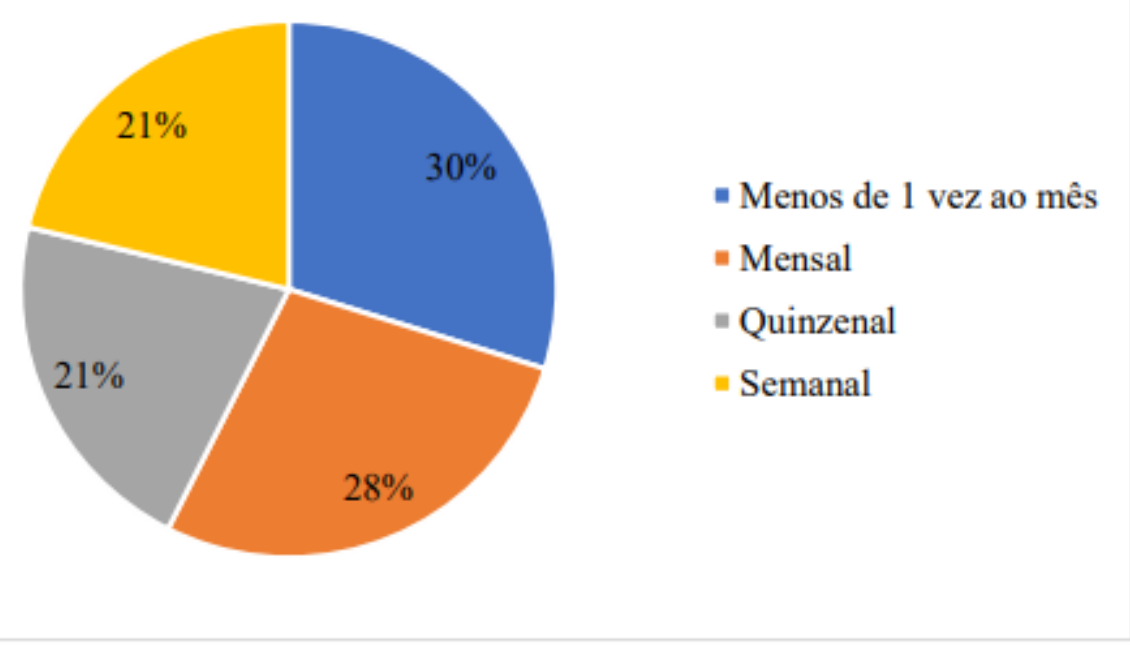

Source: Author's own production

lassifying the respondents that frequent the restaurants at least once a fortnight (49\%) as the most valuable due to the assiduity, it is worth mentioning that among them $47 \%$ usually go in the afternoon.

Figure 15 brings the average amount spent (average ticket - in reais) by the respondents each time they go to the restaurants in the commercial center of the city A. The largest portion (61\%) stated that they spend more than $\mathrm{R} \$ 20.00$ per visit, $36 \%$ from $\mathrm{R} \$$ 15.00 to $R \$ 20.00$, and only $3 \%$ from $R \$ 10.00$ to $R \$ 15.00$. This shows that customers are willing to spend more money to obtain the main attributes highlighted in Figure 12: quality and service. 


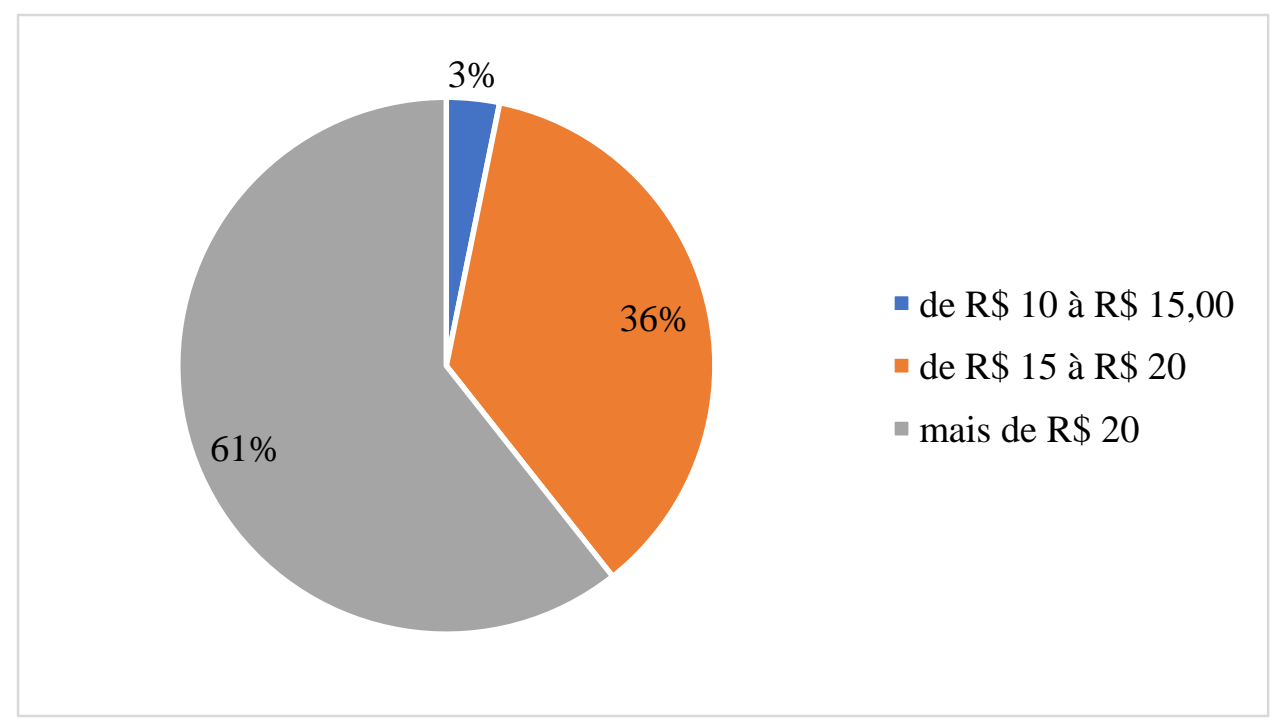

Source: Author's own production

A Tabela 1 resume os dados obtidos por meio da aplicação das dez questões de comparações multicritérios aplicadas aos entrevistados.

Table 1 - Resumo das questões de multicritérios

\begin{tabular}{lcccccc}
\hline Critérios & $\begin{array}{c}\text { Atendiment } \\
\mathrm{o}\end{array}$ & $\begin{array}{c}\text { Qualidad } \\
\mathrm{e}\end{array}$ & $\begin{array}{c}\text { Variedad } \\
\mathrm{e}\end{array}$ & Tempo & Ambiente & $\begin{array}{c}\text { Resultado } \\
\text { Geral }\end{array}$ \\
\hline Atendiment o & 1,0 & 3,0 & 7,0 & 7,0 & 7,0 & $48,9 \%$ \\
Qualidade & 0,3 & 1,0 & 5,0 & 6,0 & 6,0 & $27,6 \%$ \\
Variedade & 0,1 & 0,2 & 1,0 & 5,0 & 4,0 & $13,0 \%$ \\
Tempo & 0,1 & 0,2 & 0,2 & 1,0 & 3,0 & $6,5 \%$ \\
Ambiente & 0,1 & 0,2 & 0,3 & 0,3 & 1,0 & $4,0 \%$ \\
\hline
\end{tabular}

Source: Author's own production

The service (48.9\%) is considered the most important criterion in the process of choosing the establishment of preference of the respondents, followed by quality $(27.6 \%)$, variety $(13 \%)$, time $(6.5 \%)$ and environment $(4 \%)$. It is worth reinforcing that these results corroborate the customer preference criteria presented in Figure 13 when the reasons for choosing the preferred establishment were evaluated.

Also, aggregating the values according to the higher hierarchical level, the results show a greater relevance to the services provided (59.4\%), while the dimensions directly related to the products showed a relevance of $40.6 \%$. This demonstrates the strategic importance of employee training and development.

Evaluating the data presented in Figure 12 and the multicriteria analysis performed, the enterprise should develop strategies capable of conveying to consumers the image of a place that delivers superior quality and service compared to the main competitors mapped (six competitors with the highest relevance). Still, it is important to reinforce the estimated value that loyal customers have in this market, since a relevant portion of $12.8 \%$ goes to restaurants more than once a day and $49 \%$ at least once a fortnight.

The market analysis provides the entrepreneur with basic and relevant information for the construction of a business plan, through the appropriate treatment of the strengths and weaknesses of the company in idealization and the opportunities and threats of the external environment.

We can consider that the marketing analysis provides a theoretical foundation, with relevant information for decision making. It is also important to consider the market performance in recent periods, as well as the entrepreneur's experiences and the organizational objectives.

From this, it is possible to elaborate the SWOT Matrix. This tool proves to be useful in the analysis of the company's internal and external environments, formulating strategies that contribute to the construction of the business. Thus, when evaluating the 
Marketing Analysis for the Construction of a Business Plan: Analysis of the Restaurant Sector in the Commercial Center of a City Located in the Brazilian's Interior

results obtained in the market research, it is suggested the construction of a matrix that focuses on the establishment of strengths that take into account the points related to the external vision, as shown in Chart 4

Chart 5 - SWOT Matrix

\begin{tabular}{|c|c|}
\hline Perspectiva & Visão Externa \\
\hline Oportunidades & $\begin{array}{l}\text { - } \quad \text { Grande parcela de frequentadores assíduos da região. } \\
\text { - } \quad \text { Público heterogêneo em gênero, idade e ocupação. } \\
\text { - } \quad \text { Maior parcela da população possuí fonte de renda estabelecida. } \\
\text { - } \quad \text { Clientes dispostos a elevar seus gastos a fim de obter qualidade e atendimento } \\
\text { superiores. } \\
\text { - } \quad \text { Crescente disponibilidade de fornecedores e canais de abastecimento (indústria } \\
\text { e atacadistas). } \\
\text { - } \quad \text { Inexistência de custo para o cliente para mudança de estabelecimento. }\end{array}$ \\
\hline Ameaças & $\begin{array}{l}\text { - Maioria dos frequentadores dos restaurantes não possuem atividade fixa na } \\
\text { região. } \\
\text { - } \\
\text { estabelecimentos frequentados caso estejam satisfeitos. } \\
\text { - } \\
\text { - } \quad \text { Existência de concorrência consolidada. } \\
\text { - } \quad \text { Momento atual de estagnação da economia. } \\
\text { Grau de diferenciação dos produtos. }\end{array}$ \\
\hline
\end{tabular}

Source: Author's own production

With the crossings provided by this matrix with the possible strengths and weaknesses to be listed, one can analyze how the internal environment influences the chances of external threats and opportunities to materialize and affect the expected results, seeking to direct the entrepreneur's efforts directly on the influencers of the market competitive forces presented in Chart 2.

The enterprise should establish what its strengths and weaknesses will be, considering the opportunities and threats of the external environment, and through the four perspectives of the BSC (Figure 3), define the strategies necessary to promote alignment and control (Chart 5).

\section{Chart 6 - Balanced Scorecard}

\begin{tabular}{|c|c|}
\hline Perspectivas & Estratégias \\
\hline Financeira & $\begin{array}{l}\text { - } \quad \text { Capital de investimento necessário. } \\
\text { - } \quad \text { Prazo de retorno do investimento. - Taxa } \\
\text { Interna de Retorno necessária à viabilidade do } \\
\text { negócio. } \\
\text { - } \quad \text { Política de precificação. }\end{array}$ \\
\hline Do aprendizado e crescimento & $\begin{array}{ll}\text { - } & \text { Missão da empresa. } \\
\text { - } & \text { Visão da empresa. } \\
\text { - } & \text { Valores organizacionais. } \\
\text { - } & \text { Gerencia e organização hierárquica. - } \\
\text { Perfil do colaborador para cada uma das funções. } \\
\text { - } \\
\text { - }\end{array}$ \\
\hline & $\begin{array}{l}\text { - Gestão do conhecimento. } \\
\text { - Treinamento e desenvolvimento. }\end{array}$ \\
\hline
\end{tabular}


Marketing Analysis for the Construction of a Business Plan: Analysis of the Restaurant Sector in the Commercial Center of a City Located in the Brazilian's Interior

\begin{tabular}{|l|ll|} 
Dos clientes & $\begin{array}{l}- \\
\text { Definição de portfólio de produtos e serviços. }\end{array}$ \\
- & $\begin{array}{ll}\text { Localização. } \\
- & \text { Estratégia de comunicação. } \\
- & \text { Parcerias estratégicas. }\end{array}$ \\
\hline Dos processos internos & - & Objetivos de curto, médio e longo prazo. \\
& - & Estrutura legal e tributária. \\
& - & Armazenamento e segurança de dados. \\
\hline
\end{tabular}

Source: Author's own production

It is important to reinforce the importance of establishing strategies that are adherent to the opportunities presented in the market research carried out, considering the heterogeneity of gender, age, place of residence, the fluctuation of final activities when going to the center of the city $A$, the periods of the day they usually go, the established competition and its positive points highlighted by the interviewees and, especially, the fulfillment of the main attributes highlighted in the multicriteria assessment: service and quality.

\section{CONCLUSION}

This work had as its main objective the investigation and identification of market opportunities in the restaurant sector in the city of Lorena, in the state of São Paulo. Characterized as descriptive, it had as secondary objectives the survey of the competition present in the local market, the characteristics of the researched universe population, relating them to behaviors and consumption habits, having as central characteristic the use of strategic management precepts researched and exposed in the literature review and, finally, providing the necessary subsidies for the development of a business plan.

In the course of the study, the interpretation of the data collected contributed to the achievement of the study's main objective and to the formulation of new questions, which demonstrates the importance of the study for the formulation of a business plan capable of delivering relevant competitive advantages to the entrepreneur.

It is then concluded that the elaboration of a marketing analysis in the planning phase of an enterprise, based on the theoretical precepts of strategy for retail companies, focused on innovation and differentiation, combined with a market positioning that favors the convergence of objectives, can offer results in the short term that bring to light demands that were previously suppressed or that customers have been seeking in the competition.

In this context, due to the complexity of attributes mapped in the market and aiming at the construction of effective management processes, even if not yet addressed in this study, it is necessary to define an appropriate organizational structure, facilitating the implementation of strategies and the monitoring of results. One should choose to use a management model that is not limited to the measurement of gross sales values (billing), but to implement and manage other indicators considered important for retail. It is important to point out that in a competitive scenario in which retail companies currently find themselves, having agile processes and the ability to innovate in the short term become important characteristics and can be important strategic differentials.

During the development of the study, several opportunities and limitations presented themselves and showed themselves capable of directing the work to questions beyond those initially established. The opportunities presented themselves during the investigations and research, demonstrating the existence of contents that were not initially foreseen in the elaboration of the questionnaire used to collect market data, such as opportunities for market differentiation, communication channels between the business and the consumer market, and new food trends.

The reservations also brought limits that led to the constitution of new analysis, observation, and research tactics. Constraints were observed due to the lack of available primary information and the social context to which the research needed to submit during the application of the questionnaires, since the recommendations of social distancing, a recommended measure to contain the 2019 coronavirus dissemination (COVID19), imposed during the collection period, hindered the closeness between researcher and interviewees, a fact that made it difficult to approach people in the places where the questionnaire was applied. However, such reservations became part of the analysis of the study and were relevant for understanding the characteristics of the environment, with the local culture, the relationship with customers, and for the formulation of new questions that can collaborate to the growth of research on the development of business strategies for retail companies. 


\section{Marketing Analysis for the Construction of a Business Plan: Analysis of the Restaurant Sector in the Commercial Center of a City Located in the Brazilian's Interior}

However, during the execution of this research, it was observed that there are several gaps that do not provide a delivery of solutions in products, services, and complete shopping experience to their customers. Thus, a project that would start the work of developing strategies to meet the new demands of food retail, using resources that stimulate the participation of several areas involved in its development and impact the image in the market, the financial results and the organizational culture towards the company's strategy, has proven to be relevant.

Therefore, some important reflection questions for the continuity of a business plan should be exposed, such as

- How to deal with the obsolescence of the information in this work?

- How can we establish an effective communication with the market?

- How to develop the demand for products and services that differentiate it from other competitors?

Thus, in order to improve the studies of a market, as a provider of relevant information to the preparation of a business plan, it is suggested to collect this additional information and the continuous monitoring of the market, through reports and studies published by research institutes and business class associations. Also, in order to increase the knowledge about the strategic management of restaurants, as future works it is suggested the development of new works that address issues related to media, customer relationship, knowledge management, human resources management, and economic feasibility analysis.

\section{REFERENCES}

1) ALMEIDA, M. I. R. Manual de planejamento estratégico: desenvolvimento de um plano estratégico com a utilização de planilhas Excel. 2. ed. São Paulo: Atlas, 2003. 160 p.

2) ANSOFF, H. I. Estratégia empresarial. 1. ed. São Paulo: McGraw-Hill, 1977. 203 p.

3) ASSOCIAÇÃO BRASILEIRA DA INDÚSTRIA DE ALIMENTOS - ABIA. Evolução da indústria de alimentos (Var\% ac. em 12 Meses). Disponível em: <https://www.abia.org.br/downloads/numeros-producao-ABIA.pdf>. Acesso em: 24 ago. 2020.

4) BIZARRÓN, M. E. B.; PALACIOS, E. M. C.; SILVA, J. L. B. Factores de la satisfacción del cliente y su influencia em la competitividad de la industria restaurantera. European Scientific Journal, v.10, n. 22, p. 374-382, 2014.

5) BORBA, M. C. et al. Avaliação do Balanced Scorecard em microempresa na percepção do gestor, colaboradores e clientes. Revista de gestão e tecnologia - Navus, Florianópolis - SC, v. 8, n. 3, p. 172-185, jul./set. 2018.

6) BRIDGE, S.; HEGARTY, C. Beyond the Business Plan: 10 Principles for New Venture Explorers. 1. ed. Londres: Palgrave Macmillan, 2013. 292 p.

7) CAKICI, A. C.; AKGUNDUZ, Y.; YILDIRIM, O. The impact of perceived price justice and satisfaction on loyalty: the mediating effect of revisit intention. Tourism Review, v. 74, n. 3, p. 443-462, 2019.

8) CAMARGOS, M. A.; DIAS, A. T. Estratégia, administração estratégica e estratégia corporativa: uma síntese teórica. Caderno de pesquisas em administração, São Paulo, v. 10, n.1, p. 27-39, jan./mar. 2003.

9) DORNELAS, J. C. Empreendedorismo: transformando ideias em Negócios. 7. ed. Rio de Janeiro: Campus, 2018.288 p.

10) FERRARI, A.; MORONE, P.; TARTIU, V. E. Tackling uncertainty through business plan analysis. Agriculture, Roma, v. 6, n. 5, p. 1-12, 2016.

11) FILHO, V. A. V.; PERESIN, G. L.; NETO, M. S. Vantagem competitiva: uma releitura teórica de Porter. In: CONGRESSO VIRTUAL BRASILEIRO DE ADMINISTRAÇÃO CONVIBRA, 8., 2011, São Paulo. Congresso Virtual Brasileiro de Administração.

12) São Paulo: CONVIBRA, 2011. Disponível em: <https://www.academia.edu/25706424/Vantagem competitivaumareleiturate\%C3\%B3ricadePorter\%C3\%81reaTem\%C3\%A1ticaEstrat\% C3\%A9giaEmpresarial>. Acesso em: 28 nov. 2020.

13) GALINDO A. G. Balanced Scorecard como Sistema de Alinhamento e Controle Estratégico da Gestão. In: SIMPÓSIO DE EXCELÊNCIA EM GESTÃO E TECNOLOGIA - SEGeT, 2., 2005, Resende. Simpósio de Excelência em Gestão e Tecnologia. Resende: SEGeT - AEDB, 2005. p. 57-71.

14) GIL, A. C. Métodos e técnicas de pesquisa social. 6. ed. São Paulo: Atlas: 2008. 200 p.

15) GIL, A. C. Como elaborar projetos de pesquisa. 6. ed. São Paulo: Atlas: 2017. 188 p.

16) HITT, M.; IRELAND, R. D.; HOSKISSON, R. E. Administração estratégica: competitividade e globalização. 2. ed. São Paulo: Cengage Learning, 2011. $415 \mathrm{p}$.

17) HLADKYI, O. et al. Scientific-practical approaches to justification of location of quick service restaurants. Journal of Geology, Geography and Geoecology, v.28, n. 4, p. 649660, 2019.

18) KAPLAN, R. S.; NORTON, D. P. Organização orientada para a estratégia: Como as empresas que adotam o balanced scorecard respiram no novo ambiente de negócios. 21. ed. Rio de Janeiro: Elsevier, 2000. 407 p. 
19) KELM, M. S. et al. A Inovação como Estratégia Competitiva das Organizações: Um Ensaio Teórico. RAIMED - Revista de Administração IMED, v.4, n.3, p. 274-285, ago./dez. 2014.

20) KOTLER, P.; ARMSTRONG, G. Princípios de Marketing. 9. ed. São Paulo: Prentice Hall, 2003. 560 p.

21) KOTLER, P.; KELLER, K. L. Administração de marketing. 14. ed. São Paulo: Pearson Education do Brasil, 2012.765 p.

22) KUKANJA, M.; OMERZEL, D. G.; BUKOVEC, B. A restaurant quality model based on marketing factors. Journal E\&M Economics and Management, v. 20, n.1, p. 157-17, 2017.

23) LEE, T-R. et al. The sequence of strategies when establishing Taiwanese restaurant in Thailand. European Business Review, 2020. Disponível em: <https://doi.org/10.1108/EBR-03-2017-0050>. Acesso em: 29 nov. 2020.

24) LIPPEL, I. L. Gestão de custos em restaurantes: utilização do método ABC. 2002. 170f. Dissertação (Mestrado em Engenharia de Produção) - Universidade Federal de Santa Catarina, Florianópolis, 2002.

25) LOBATO, D. M.; FILHO, J. M.; TORRES, M. C. S. Estratégia de empresas. 9. ed. Rio de Janeiro: Editora FGV, 2005.175 p.

26) MADRUGA, R. P. et al. Administração de marketing no mundo contemporâneo. 1. ed. Rio de Janeiro: Editora FGV, 2004. $140 \mathrm{p}$.

27) MARINHO, E. Z. et al. Análise estratégica de um porto do estado do Rio de Janeiro: aplicação da matriz SWOT. Mundo Livre: Revista Multidisciplinar, Campos dos Goytacazes, v.5, n.2, p. 21-39, ago./dez. 2019.

28) MIGUEL, P. A. C. et al. Metodologia de pesquisa em engenharia de produção e gestão de operações. 2. ed. Rio de Janeiro: Elsevier: ABEPRO, 2012. 280 p.

29) MOLINA, M. A. C et al. Implementing the balanced scorecard: its effect on the job environment. Total Quality Management \& Business Excellence, v.27, n.1-2, p. 81-96, 2016.

30) MUÑOZ, B.; ROMANA, M. G.; ORDÓNEZ, J. Sensitivity analysis of multicriteria decision making methodology developed for selection of typologies of earth-retaining walls in an urban highway. In: CONFERENCE ON TRANSPORT ENGINEERING, 12., 2016, Valencia, Spain. Conference on Transport Engineering. Valencia, Spain: CIT, 2016. p.135-139.

31) MCGEE, J.; PRUSAK L. Gerenciamento estratégico da informação: planejamento e alinhamento estratégico nas organizações. Tradução de Astrid Beatriz de Figueiredo. 4. ed. Rio de Janeiro: Campus, 1994. 244 p.

32) OCKE, M.; GUEDES, G. D.; SILVA, M. A. S. Gestão estratégica de marcas no setor de food service em Florianópolis. Caderno Profissional de Marketing UNIMEP, Florianópolis, v.8, n. 1, p. 49-72, jan./mar. 2020.

33) OLIVEIRA, L. A estratégia organizacional na competitividade: um estudo teórico. Revista eletrônica de administração REAd, v. 10, n. 4, p.1-23, jul./ago. 2004.

34) OLIVEIRA, M. S.; MORETTI, S. L. A.; POZO, H. A hospitalidade e a gestão de restaurantes: evidências de um estudo múltiplo de caso em São Paulo. Revista Rosa dos Ventos - Turismo e Hospitalidade, v. 7, n. 1, p. 20-33, jan./mar. 2015.

35) PEREIRA, G. G. Plano de negócios: empresa no setor da restauração e animação. 2015. 63f. Dissertação (Mestrado em Ciências Empresariais) - Universidade de Lisboa, Instituto Superior de Economia e Gestão, Lisboa, 2015.

36) PEZENKA, I.; WEISMAYER, C. Which factors influence locals' and visitors' overall restaurant evaluations? International Journal of Contemporary Hospitality Management, v. 32, n. 9, p. 2793-2812, 2020.

37) PINTO, L. F. G. Planejamento estratégico. 1. ed. Londrina: Editora e Distribuidora Educacional S.A., 2016.224 p.

38) PORTER, M. E. A vantagem competitiva das Nações. 14. ed. Rio de Janeiro: Campus, 1993. 897 p.

39) PORTER, M. E. Estratégia competitiva: técnicas para análise de indústrias e da concorrência. 1. ed. Rio de Janeiro: Atlas, 2005. 448 p.

40) RAJPUT, A.; GAHFOOR, R. Z. Satisfaction and revisit intentions at fast food restaurants. Future Business Journal, v. 13, n.6, p. 1-12, 2020.

41) RODRIGUES, M. R. A. Estratégia de empresas. 9. ed. Rio de Janeiro: Editora FGV, 2014. 175 p.

42) RODRIGUES, V. M.; OLIVEIRA, U. R. Indicadores de desempenho para micro e pequenas empresas - um estudo de campo no município de Volta Redonda. Revista Valore, Volta Redonda, v. 5, e-5006, 2020.

43) SILVA, H. H. C. et al. Planejamento estratégico de marketing. 4. ed. Rio de Janeiro: Editora FGV, 2011.144 p.

44) SIOPA, C. et al. Consumer profile of Portuguese local food restaurants. European Journal of Tourism - Hospitality and Recreation, v. 7, n. 2, p.112-116, 2015.

45) SOUZA, M. S. P.; SILVA, M. B. F. A. Avaliação do mix de marketing de serviços e análise da concorrência. Um estudo em uma empresa no ramo de restaurantes do centro oeste mineiro. In: SIMPÓSIO DE EXCELÊNCIA EM GESTÃO E TECNOLOGIA -SEGeT, 12., 2015, Resende. Simpósio de excelência em gestão e tecnologia. Resende: SEGeT - AEDB, 2015. p. 1-14. 
Marketing Analysis for the Construction of a Business Plan: Analysis of the Restaurant Sector in the Commercial Center of a City Located in the Brazilian's Interior

46) TEIXEIRA, C. A. C.; DANTAS, G. G. T.; BARRETO, C. A. A importância do planejamento estratégico para as pequenas empresas. Revista eletrônica científica da FAESB, Tatuí - São Paulo, v. 1, n. 2, p. 104-123, 2015.

47) VIEIRA, F. R. C. Dimensões para o diagnóstico de uma gestão estratégica voltada para o ambiente de empresas de pequeno porte. 2002. 213f. Tese (Doutorado em Engenharia de Produção) - Universidade Federal de Santa Catarina, Florianópolis, 2002.

48) VENTURI, J. L. Estudo das características empreendedoras dos proprietários de restaurantes na cidade de Itapema, conforme a abordagem de David McClelland. 2003. 113f. Dissertação (Mestrado em Turismo e Hotelaria) - Universidade do Vale do Itajaí, Balneário Camboriú, 2003.

49) YEMBERGENOV, R.; ZHARYLKASINOVA, M. Management accounting in the restaurant business: organization methodology. Entrepreneurship and Sustainability Issues, v. 7, n. 2, p. 1542-1554, 2019.

50) YEMCHUK, T.; ARPUL, O. Competitive Positions in Restaurant Business in PresentDay Conditions Based on the Example of Chernivtsi. Studies of the Industrial Geography Commission of the Polish Geographical Society, v. 34, n. 1, p. 92-107, 2020.

51) WRIGHT, P.; KROLL, M.; PARNELL, J. Administração Estratégica: conceitos. 1. ed. São Paulo: Atlas, 2009. 440 p. 